\title{
Integrated Review of Lifestyle Interventions Targeting Diet and Exercise in Early or First-Episode Psychosis
}

\author{
Chris Griffiths*, Farah Hina \\ Innovation and Research Department, Northamptonshire Healthcare NHS Foundation Trust, Northampton, UK \\ Email: *Chris.Griffiths@nhft.nhs.uk
}

How to cite this paper: Griffiths, C. and Hina, F. (2021) Integrated Review of Lifestyle Interventions Targeting Diet and Exercise in Early or First-Episode Psychosis. Open Journal of Psychiatry, 11, 265-278. https://doi.org/10.4236/ojpsych.2021.11402 1

Received: August 16, 2021

Accepted: September 27, 2021

Published: September 30, 2021

Copyright $\odot 2021$ by author(s) and Scientific Research Publishing Inc. This work is licensed under the Creative Commons Attribution International License (CC BY 4.0).

http://creativecommons.org/licenses/by/4.0/

\begin{abstract}
Aims: Life expectancy is reduced by $10-20$ years in psychotic disorders compared with the general population, largely due to high incidence of physical health disorders: heart attack, stroke, obesity, cardiovascular disease (CVD), and type 2 diabetes. Early or first-episode psychosis patients can be especially vulnerable to physical health, psychological and social consequences of antipsychotic medication weight gain. The aim of this paper is to review diet and exercise lifestyle interventions employed to address these issues. Method: A review of research evidence on lifestyle interventions (diet and exercise) for individuals with early or first-episode psychosis (2000 to 2020) was undertaken. An internet-based literature search employed Medline, PsycINFO, Embase, PubMed and Web of Science. Results: Nine studies meeting the criteria were identified: comprising of three exercise intervention studies, one diet intervention study, and five combined diet and exercise intervention studies. Only one study used a RCT design with prior power analysis to determine participant numbers, two had a RCT design, two had a comparison group and four had no control group. Overall, these studies show that exercise and diet focused interventions may provide beneficial physical and mental health outcomes, but participant engagement and behaviour change may be difficult to achieve in early or first-episode psychosis due to individual factors associated with the experience of psychosis and medication prescribed, and health service related factors. Conclusion: There is a need for evidence-based lifestyle programmes in early or first-episode psychosis that includes individually targeted evidence based exercise and diet interventions. Further appropriately powered RCTs are required to strengthen the evidence base.
\end{abstract}

\section{Keywords}

Early, First-Episode, Psychosis, Diet, Exercise, Lifestyle, Behaviour Change 


\section{Introduction}

Psychosis is defined as the experience of false beliefs (delusions) or false sensory perceptions (hallucinations) and lacking insight [1]. Psychotic disorders include schizophrenia, schizoaffective disorder, schizophreniform disorder, bipolar disorder delusional disorder, and severe depression [1]. Population prevalence of psychosis disorders per 1000 at a single point is 3.9 , over 12 -months is 4 , and over lifetime is 7.5 [2]. The term first-episode psychosis (FEP) or early psychosis is typically used to refer to the early course of a psychotic illness or treatment; "recent-onset psychosis" is an alternate term used [3].

Compared with the general population, individuals who experience psychosis and go on to receive a diagnosis of schizophrenia have an external cause mortality from that is 12 -fold higher; the high mortality rate is mostly explained by unhealthy lifestyles and a high incidence of somatic comorbidities [4] [5]. People with mental health disorders (including psychotic disorders) have a $10-20$ years reduced life expectancy compared with the general population [6]. This reduced life expectancy is mostly due to elevated incidence of physical health disorders such as heart attack, stroke, obesity, cardiovascular disease (CVD), and type 2 diabetes (T2D) [7] [8].

Antipsychotic medications raise cholesterol, triglyceride levels, and arterial hypertension, and impair glucose metabolism, causing metabolic syndrome (MetS) and elevated risk of diabetes and CVD [9]. MetS is diagnosed when a minimum of three interlinked cardiovascular risk-factors are present: hyperglycemia, abdominal obesity, hypertension, high triglycerides, and low high-density lipoprotein (HDL) cholesterol levels [9]. At 41\% MetS prevalence in schizophrenia in a North American population is approximately double the North American general population prevalence [10]; and at 19\% in a north European schizophrenia population is treble a north European general population prevalence [11]. The presence of MetS and metabolic risk factors in schizophrenia links to significantly reduced aerobic fitness [12] and cognitive impairment (potentially contributing to functional decline) [13].

In psychotic disorders, obesity is a major contributor to cognitive impairment and decline in cognitive functioning [13]. Even early in psychosis progression, overweight/obesity may be an independent diffuse brain alterations risk factor which manifests as advanced brain aging, highlighting the need to target metabolic health and intervening early in relation to overweight/obesity to possibly slow brain ageing [14]. In the general population, evidence suggests that weightreduction programmes can improve cognitive function [15].

To benefit health, the World Health Organisation (WHO) recommends adults engage in a per week minimum of 150 minutes moderate or 75 minutes highintensity physical activity [16]. Whether multimorbidity exists or not, healthier lifestyles can enable increased life expectancy ( 6.3 yrs. for men; 7.6 yrs. for women) [17]. Intrapersonal factors such as self-efficacy and motivation are correlates of physical activity behaviour [18]. In clinical disease or inactive populations, 
relatively small increases in physical activity have been linked to marked clinically relevant improvements in health status [18].

Psychosis disorder patients often have reduced cardiovascular fitness and physical activity, as well as increased sedation [19] [20] [21] [22]. Decreased physical activity in schizophrenia diagnosis is correlated with increased social withdrawal and reduced motivation, social functioning, and quality of life [23]; as well as increased severity of depressive and negative cognitive symptoms [19]. Sedation and lack of physical activity are linked to depression, lower wellbeing, hopelessness, poorer quality of life, CVD, stroke, hypertension, diabetes, osteoarthritis, and chronic obstructive pulmonary disease (COPD) [18] [24] [25].

Regular physical activity benefits well-being; and as a primary and secondary preventative strategy is effective against over 25 chronic medical conditions [18]. For people with psychosis, engaging in physical exercise is linked to improved quality of life, cognition, functioning and physical health; and a reduction of positive and negative psychotic symptomatology [26]. Further benefits of physical activity are improved functioning, for example, at work, in independent living, self-care, and in social network relationships [27]. Interventions to increase physical exercise can effectively enhance physical and mental health [28] [29].

Two thirds of early or first-episode psychosis patients have clinically significant weight gain ( $\geq 7 \%)$ in their first 12 months of antipsychotic medication [30]. People receiving anti-psychotic medication report increased hunger, night-time hunger, cravings for sweet foods and drinks, and decreased feeling of satiety [31] [32]. Addressing weight gain early in psychosis experience is paramount as it is linked to poor antipsychotic treatment adherence, worse clinical outcomes, reduced quality of life, increased social stigma, greater morbidity, and raised mortality [33]. People with severe mental illness (SMI) (including early or first-episode psychosis) have a poorer dietary intake than the general population and a 2 - 3 fold increased obesity rates: known risk factors for T2D [34] [35] [36].

A review of diet and psychosis reported the benefits of adopting a Mediterranean diet [37], and this links to recommendations for the general population to adopt the flexitarian diet [38]. To have a therapeutic effect in treating the comorbidities associated with psychosis, a diet that contains sufficient fruits and vegetables; high-fibre foods; $\omega$-3 fatty acids; vitamin B12; folate; vitamin B6; zinc; dietary protein; protein sources high in glycine; lysine, serine, and tryptophan; and vitamin C is recommended [37].

Previous reviews of lifestyle interventions in psychosis/schizophrenia [39] [40] [41], have been criticised by for not including all available studies and not assessing research design quality [42]. A systematic review of 11 studies found that lifestyle interventions incorporating psychoeducation, diet advice, and physical activity guidance were associated with significant reduction in weight, waist circumference, and blood glucose levels; concluding that evidence based healthier lifestyle promotion interventions within mental healthcare are essential [43]. The review's focus was on interventions in schizophrenia, and found that studies had limited sample sizes and other methodological quality issues. A separate 
systematic review of studies comparing lifestyle interventions with a control group for psychotic disorders patients found 25 RCTs; only four were deemed high quality, and these showed an overall effect on reducing bodyweight [42]. Out of the 25, ten studies showed that lifestyle interventions led to significant improvements in cardiometabolic risk factors: triglycerides, fasting glucose and insulin [42].

Interventions directed at reducing weight gain, improving diet and improving physical activity in psychosis/schizophrenia are needed [11]. The aim of the present paper is to review and summarise lifestyle interventions (diet and exercise) for individuals with early or first-episode psychosis. This paper seeks to answer the questions: "what is the need for, acceptability of and effect of lifestyle behaviour interventions in early/first-episode psychosis on physical and mental health outcomes?" and "what are the outcomes that these interventions seek to have an impact on?"

\section{Methods}

Inclusion criteria for intervention studies

1) Peer-reviewed published literature and $\mathrm{PhD}$ dissertations

2) Participants with psychotic disorder

3) Exercise or diet related interventions

4) No restriction on geographical location

5) Studies with either males, females or both

6) Published in or translated into English

7) Published from the January 2000 to December 2020

\section{Search strategy}

An internet-based search was carried out. The following electronic databases were used: Medline, PsycINFO, Embase, PubMed and Web of Science. Full search terms are provided below. The reference list of the retrieved articles, tables of contents of relevant journals, recent systematic reviews and meta-analyses of interventions were scanned to identify potential further studies for inclusion in the review.

Search terms

Psychosis:

- First episode or First-episode or First or Primary or Early or FEP

- Psychosis or Psychoses or Psycho* or Psychot* or Antipsychotic Exercise:

- Physical $^{\star}$ or Physical activit ${ }^{\star}$ or Exercise* or Motor activit $^{\star}$ or Sport ${ }^{\star}$ or physical training or Exercise intervention or Physical fitness

- Gym or Workout or Work-out or Lifestyle intervention or Strengths training or Aerobic or Anaerobic

Diet:

- Diet or Nutrition

- Body weight or Weight loss or Weight management or Health or Obesity 


\section{Results}

Following the screening process and removal of duplications from the $864 \mathrm{ob}-$ tained papers, 9 relevant papers with diet and/or exercise interventions in early or first-episode psychosis were identified. In terms of screening criteria, the first phase retained studies with interventions focussed on diet and/or exercise in first-episode or early psychosis. In the second phase, the reference lists of the 19 papers identified from phase one were further examined for relevant papers, and were found were included. Figure 1 provides full details of the processes carried out in the two screening phases. Refer to Tables 1-3 for details of the included studies.

\section{Discussion}

Diet and exercise focused interventions with various components have been applied

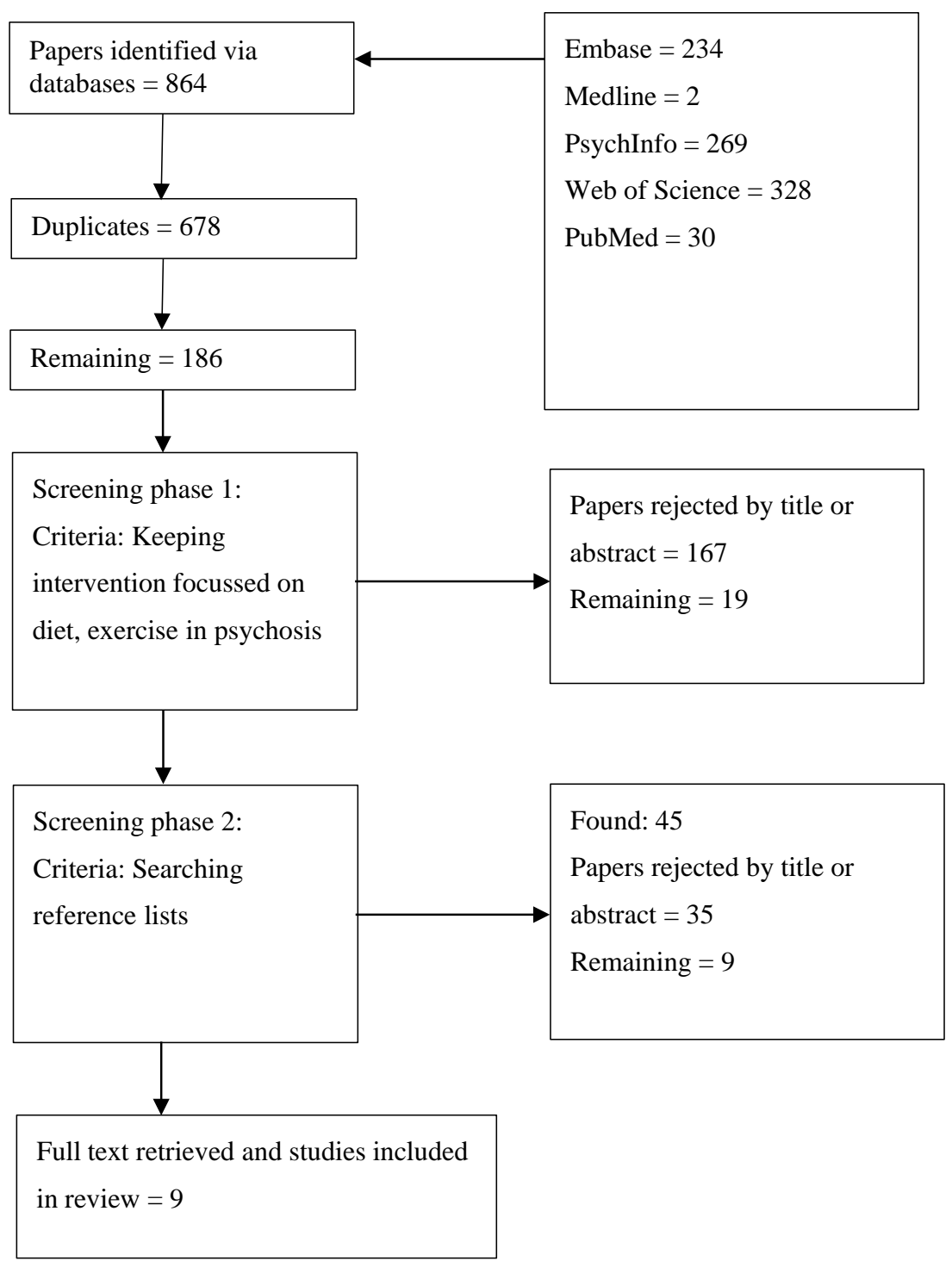

Figure 1. Flow chart of results. 
Table 1. Exercise focused lifestyle interventions.

\begin{tabular}{|c|c|c|c|c|c|}
\hline Author/year & Aim & Participants & Design/Measures & Intervention & Results \\
\hline $\begin{array}{l}\text { Abdel-Baki et al. } \\
\text { (2013) }\end{array}$ & $\begin{array}{l}\text { To assess the feasibility } \\
\text { of implementing a } \\
\text { 14-week aerobic interval } \\
\text { training (AIT) program } \\
\text { and its efficacy in } \\
\text { improving metabolic } \\
\text { outcomes and } \\
\text { cardiorespiratory fitness }\end{array}$ & $\begin{array}{l}\text { Twenty-five (16 } \\
\text { completed) male } \\
\text { subjects with FEP }\end{array}$ & $\begin{array}{l}\text { No control group. } \mathrm{VO}_{2} \text { max } \\
\text { was estimated with the single } \\
\text { treadmill walking test, } \\
\text { anthropometric measures, } \\
\text { metabolic profiles (fasting } \\
\text { blood work), blood pressure, } \\
\text { resting heart rate, body } \\
\text { composition was estimated by } \\
\text { bioelectric impedancemetry } \\
\text { analysis. Other measures: } \\
\text { Clinical Global Impression } \\
\text { Severity Subscale (CGI-S), } \\
\text { Global Assessment of } \\
\text { Functioning Scale (GAF), } \\
\text { Social and Occupational } \\
\text { Functioning Assessment Scale } \\
\text { (SOFAS) }\end{array}$ & $\begin{array}{l}\text { Aerobic interval } \\
\text { training (AIT) } \\
\text { involved a } \\
\text { supervised session } \\
\text { of warm-up and } \\
\text { treadmill running } \\
\text { twice a week } \\
\text { (14 weeks) }\end{array}$ & $\begin{array}{l}\text { A significant decrease in } \\
\text { waist circumference ( } \mathrm{WC} \text {; } \\
-4.3 \mathrm{~cm} ; \mathrm{p}=0.015) \text {, resting } \\
\text { heart rate }(-8.6 \mathrm{bpm} ; \mathrm{p}= \\
0.05) \text { and a } 38 \% \text { increase in } \\
\left.\mathrm{VO}_{2} \text { max ( } \mathrm{p}=0.001\right) \text {. No } \\
\text { significant change in blood } \\
\text { pressure, lipid profile, } \\
\text { glucose metabolism or } \\
\text { psychiatric measures }\end{array}$ \\
\hline Firth et al. (2018) & $\begin{array}{l}\text { Assess the feasibility of } \\
\text { an exercise intervention } \\
\text { for early psychosis and } \\
\text { to determine if it was } \\
\text { associated with changes } \\
\text { in physical and mental } \\
\text { health }\end{array}$ & $\begin{array}{l}\text { Intervention } \mathrm{N}=31 \\
\text { comparison control } \\
\text { group } \mathrm{N}=7 \\
\text { patients with FEP } \\
\text { recruited from } \\
\text { early intervention } \\
\text { services }\end{array}$ & $\begin{array}{l}\text { Non-randomised feasibility } \\
\text { trial using comparison data } \\
\text { from the treatment-as-usual } \\
\text { (TAU) control group. } \\
\text { Measures: Positive and } \\
\text { Negative Syndrome Scale } \\
\text { (PANSS), Becks Depression } \\
\text { Inventory (BDI-II), Social } \\
\text { Interaction Anxiety Scale } \\
\text { (SIAS), Socio-Occupational } \\
\text { Functioning Assessment Scale } \\
\text { (SOFAS), WHO Disability } \\
\text { Assessment Schedule } \\
\text { (WHODAS), WHO Quality of } \\
\text { Life Brief (WHOQOL-BREF), } \\
\text { body mass index, waist }\end{array}$ & $\begin{array}{l}10 \text {-week } \\
\text { individualized } \\
\text { exercise } \\
\text { intervention, } \\
\text { aiming to achieve } \\
\geq 90 \text { min of } \\
\text { moderate-to- } \\
\text { vigorous activity } \\
\text { per week }\end{array}$ & $\begin{array}{l}\text { Retention: } 81 \% \text {. On } \\
\text { average, participants } \\
\text { achieved } 107 \text { minutes of } \\
\text { moderate-to-vigorous } \\
\text { exercise each week. PANSS } \\
\text { scores decreased by } 13.3 \\
\text { points, significantly more } \\
\text { than control group. } \\
\text { Psychosocial functioning } \\
\text { and verbal short-term } \\
\text { memory were significantly } \\
\text { improved. Increases in } \\
\text { cardiovascular fitness and } \\
\text { processing speed were } \\
\text { positively associated with } \\
\text { the amount exercise }\end{array}$ \\
\hline
\end{tabular}

Table 2. Diet focused lifestyle interventions.

\begin{tabular}{|c|c|c|c|c|c|}
\hline Author/year & Aim & Participants & Design/Measures & Intervention & Results \\
\hline $\begin{array}{l}\text { Teasdale et al. } \\
(2016 ; 2019)\end{array}$ & $\begin{array}{l}\text { Assess the efficacy } \\
\text { and acceptability of } \\
\text { nutritional } \\
\text { intervention early in } \\
\text { FEP and evaluate the } \\
\text { effectiveness of early } \\
\text { dietary intervention } \\
\text { on key nutritional end } \\
\text { points }\end{array}$ & $\begin{array}{l}\text { Twenty-seven } \\
\text { participants were } \\
\text { recruited from a } \\
\text { community-based } \\
\text { network primarily } \\
\text { targeting young people } \\
15 \text { - } 25 \text { years of age with } \\
\text { newly diagnosed FEP }\end{array}$ & $\begin{array}{l}\text { No control group. } \\
\text { Dietary Questionnaire } \\
\text { for Epidemiological } \\
\text { Studies (DQES), } \\
\text { Australian } \\
\text { Recommended Food } \\
\text { Score (ARFS), } \\
\text { discretionary food } \\
\text { intake was measured } \\
\text { by daily intake (g) }\end{array}$ & $\begin{array}{l}\text { In a } 12 \text {-week } \\
\text { intervention, } \\
\text { individual dietetic } \\
\text { consultations and } \\
\text { practical group } \\
\text { sessions were offered } \\
\text { as part of a broader } \\
\text { lifestyle programme. } \\
\text { Participants also had } \\
\text { the opportunity to } \\
\text { take part in a weekly } \\
\text { sports group and had } \\
\text { access to an on-site } \\
\text { gym supervised by an } \\
\text { exercise physiologist }\end{array}$ & $\begin{array}{l}18(67 \%) \text { completed the } \\
\text { programme. Discretionary } \\
\text { food consumption }(-47 \%) \text {, } \\
\text { daily energy intake ( }-24 \%) \\
\text { and Na (-26\%) were reduced. } \\
\text { Quality of diets improved } \\
\text { significantly, although this } \\
\text { result was not significant after } \\
\text { Bonferroni correction. The } \\
\text { principal factor contributing } \\
\text { to improved diet quality was } \\
\text { increased vegetable intake. } \\
\text { Sustained efficacy of dietary } \\
\text { intervention at } 2 \text { year } \\
\text { follow-up. Disposable food } \\
\text { consumption was } 40 \% \text { lower } \\
\text { and no rise in weight or } \\
\text { waist-circumference }\end{array}$ \\
\hline
\end{tabular}


Table 3. Mixed diet and exercise lifestyle interventions.

\begin{tabular}{|c|c|c|c|c|c|}
\hline Author/year & Aim & Participants & Design/Measures & Intervention & Results \\
\hline $\begin{array}{l}\text { Teasdale et al. } \\
(2016 ; 2019)\end{array}$ & $\begin{array}{l}\text { Assess the efficacy } \\
\text { and acceptability of } \\
\text { nutritional intervention } \\
\text { early in FEP and } \\
\text { evaluate the } \\
\text { effectiveness of early } \\
\text { dietary intervention } \\
\text { on key nutritional end } \\
\text { points }\end{array}$ & $\begin{array}{l}\text { Twenty-seven } \\
\text { participants were } \\
\text { recruited from a } \\
\text { community-based } \\
\text { network primarily } \\
\text { targeting young people } \\
15 \text { - } 25 \text { years of age with } \\
\text { newly diagnosed FEP }\end{array}$ & $\begin{array}{l}\text { No control group. } \\
\text { Dietary Questionnaire } \\
\text { for Epidemiological } \\
\text { Studies (DQES), } \\
\text { Australian } \\
\text { Recommended Food } \\
\text { Score (ARFS), } \\
\text { discretionary food } \\
\text { intake was measured } \\
\text { by daily intake (g) }\end{array}$ & $\begin{array}{l}\text { In a } 12 \text {-week } \\
\text { intervention, } \\
\text { individual dietetic } \\
\text { consultations and } \\
\text { practical group } \\
\text { sessions were offered } \\
\text { as part of a broader } \\
\text { lifestyle programme. } \\
\text { Participants also had } \\
\text { the opportunity to } \\
\text { take part in a weekly } \\
\text { sports group and had } \\
\text { access to an on-site } \\
\text { gym supervised by an } \\
\text { exercise physiologist }\end{array}$ & $\begin{array}{l}18(67 \%) \text { completed the } \\
\text { programme. Discretionary } \\
\text { food consumption }(-47 \%), \\
\text { daily energy intake }(-24 \%) \\
\text { and } \mathrm{Na}(-26 \%) \text { were reduced. } \\
\text { Quality of diets improved } \\
\text { significantly, although this } \\
\text { result was not significant after } \\
\text { Bonferroni correction. The } \\
\text { principal factor contributing } \\
\text { to improved diet quality was } \\
\text { increased vegetable intake. } \\
\text { Sustained efficacy of dietary } \\
\text { intervention at } 2 \text { year } \\
\text { follow-up. Disposable food } \\
\text { consumption was } 40 \% \text { lower } \\
\text { and no rise in weight or } \\
\text { waist-circumference }\end{array}$ \\
\hline
\end{tabular}

to address the important issue of the physical and mental health effects associated with the experience of early or first-episode psychosis and the medication used to treat psychosis. Outcomes most often targeted in the interventions reviewed were weight related factors (all of the studies), followed by fitness related factors (8 of 9) and mental health related factors (5 of 9). The present review found three studies with an exercise focused intervention, one with a diet focused intervention and five with a mixed diet and exercise intervention. Of the studies identified, only one used a RCT design with prior power analysis to ensure a sufficient sample size for statistical analysis; however, this study did not find significant change [44]. Two employed a RCT design [45] [46], two had a comparison group [47] [48]; the remaining studies did not have a control group.

Only one intervention reviewed focused solely on diet. The findings revealed individual dietetic consultations and practical group sessions are feasible and acceptable leading to a reduction in food, energy and salt intake-these improvements were sustained at a 2 year point [49] [50]. This study lacked a control group, and the intervention should be the subject of an effectively powered and appropriately designed RCT to test effectiveness. Available evidence suggests that interventions to improve the diet of people who experience psychosis are low risk, low cost, and beneficial to improve health [37].

Three studies reviewed had an exercise only focused intervention. If you can get people to do intensive twice weekly supervised exercise sessions for 14 weeks this can be beneficial to waist circumference and fitness [51]. However, sustainability and acceptability of the intervention is questionable as illustrated by the intervention's low adherence and high drop-out rate [51]. When exercise intervention is individualized, and either supported through facilitated access or supervision, it can be beneficial for mental and physical health, and cognitive and psychosocial functioning outcomes [48]. Whilst not appealing to many people, 
weekly programme of structured group exercise can produce reductions in selfrated needs for care [52]. These three studies indicate that factors which appear to be important for increasing physical exercise are individual choice, support, and coaching.

Five studies reviewed included both diet and exercise focused interventions. Ten to fourteen individual sessions offered over three-months inclusive of assessment, psychoeducation, dietary counselling, an exercise program as well as behaviour therapy can attenuate antipsychotic-induced weight gain; sessions may have to be available for longer or have booster sessions to maintain preventative effects [45]. An intervention based on behaviour change theories and group sessions targeting diet and exercise are acceptable, but do not have a significant effect on weight reduction, physical activity, dietary intake or biochemical measures [44]; however, the population was mainly drawn from those with established psychosis not first-episode psychosis. A 12-week individualised intervention comprising dietetic support, health coaching, supervised exercise prescription and, where appropriate, switching antipsychotic medication to more weight neutral medication resulted in significantly less weight gain; thus potentially reducing future disease risk [47]. The InterACT trial found a healthy-living intervention (eight individual sessions plus optional group activities over a year to encourage physical activity, improve healthier diet, and reduce weight gain) does not reduce weight or prevent weight gain. Nevertheless, patients reported goal-setting to be a helpful tool [46]. Weekly sessions containing safe behaviour education and a facilitated exercise session produced no changes in clinical variables, but participants reported it had a positive effect on their health behaviours [53]. Overall, these studies show that engaging in exercise and adopting a healthier diet (positive behaviour change) and subsequent beneficial outcomes is possible for some participants, but improved outcomes can be difficult to achieve for many people with early or first-episode psychosis.

Efforts to improve physical health have encountered patient related barriers on both a practical (money for clothing, equipment and travel) and psychological level (psychotic symptoms, feelings of vulnerability, social anxiety, depression, generalised anxiety, low motivation, and low self-efficacy) [52] [53]. Additionally, service-level barriers exist, including a lack of: resources to adopt and scale-up successful intervention programs, appropriate facilities, staff capacity, trained staff, and leadership engagement [53]. Important factors in patient engagement and retainment are flexible attendance, scheduling and progression, and priority for enjoyment, choice, and autonomy [52].

It is important to seek to overcome barriers to provide interventions that can improve the physical health of people experiencing first-episode psychosis. If levels of clinically overweight and obesity can be reduced this can positively impact a person's cognition, functioning, and brain ageing [13] [14] [15]; as well as reduced risk of diabetes, cancer and CVD [9]. If levels of physical activity can be increased this can improve quality of life, functioning (at work, independent living/self-care, and social functioning), cognition, mood, motivation, wellbeing, 
and hope; as well as reduce prevalence and risk of depression, hopelessness, CVD, stroke, hypertension, osteoarthritis, diabetes, and COPD [12] [18] [19] [20] [23] [24] [25].

\section{Limitations}

A limitation of the current review is that non-English language studies were excluded. As the present review was exploratory in nature, the research questions were intentionally open. Limitations observed in the included studies were small sample sizes and poor design (e.g. lack of RCTs based on power analysis). It was not appropriate to group studies into different categories of interventions and conduct combined analysis, as there were insufficient studies on any specific type of intervention. The combined lack of available studies and poor research design meant systematic quality assessment was unsuitable and narrative analysis was carried out instead.

\section{Conclusions}

Regular physical exercise, a balanced healthy diet and appropriate calorie intake are beneficial, safe and relatively low cost options for early or first-episode psychosis services to target. Healthy lifestyles, appropriate diet and physical activity interventions should be included in mental healthcare service treatment and prevention strategies [54]. There is a need for the development and deployment of evidence-based lifestyle programmes for people experiencing first-episode or early psychosis that include an effective combination of individually targeted exercise and diet interventions. Lifestyle interventions should be provided alongside other evidence based psychosocial and pharmacological treatments for early psychosis from the initiation of service engagement and treatment; and, where appropriate, should be included in clinical guidelines.

Younger psychosis patients are particularly vulnerable to the poor physical health, psychological and social consequences of weight gain, justifying the need to implement adjunctive interventions to prevent weight gain when antipsychotic treatment is commenced [30]. Although the present paper's review found patient acceptability and engagement for interventions was generally high, there was a limited amount of available research literature; furthermore the majority of studies reviewed were of relatively poor research design quality. Future appropriately powered RCTs are required to investigate the potential benefits of diet and exercise focused interventions.

It is important to assess the long term impact of interventions with follow-up assessments (for example, 1 or 2 years and later if possible) to determine whether healthy lifestyles are maintained. The long term enhancement of individual responsibility, self-management and sustained behaviour change to incorporate regular physical exercise and a balanced healthy diet will generate better health and wellbeing, reduce mortality rates, increase life expectancy and positively impact disability-adjusted life years (DALY). It is recommended that researchers 
investigating effects of lifestyle interventions report an impact on both physical and mental health outcomes, and employ both self-report and objective measures (e.g. weight, steps) in the research.

\section{Conflicts of Interest}

Authors have no conflicts of interest, and the work was not supported or funded by a company.

\section{References}

[1] APA American Psychiatric Association (2013) Diagnostics and Statistical Manual of Mental Disorders. American Psychiatric Publishing, Arlington. https://doi.org/10.1176/appi.books.9780890425596

[2] Moreno-Küstner, B., Martin, C. and Pastor, L. (2018) Prevalence of Psychotic Disorders and Its Association with Methodological Issues. A Systematic Review and Meta-Analyses. PLOS ONE, 13, e0195687. https://doi.org/10.1371/journal.pone.0195687

[3] Breitborde, N.J., Srihari, V.H. and Woods, S.W. (2009) Review of the Operational Definition for First-Episode Psychosis. Early Intervention in Psychiatry, 3, 259-265. https://doi.org/10.1111/j.1751-7893.2009.00148.x

[4] Hällgren, J., Ösby, U., Westman, J. and Gissler, M. (2019) Mortality Trends in External Causes of Death in People with Mental Health Disorders in Sweden, 1987-2010. Scandinavian Journal of Public Health, 47, 121-126. https://doi.org/10.1177/1403494818758912

[5] Schmitt, A., Maurus, I., Rossner, M.J., Röh, A., Lembeck, M., von Wilmsdorff, M., Malchow, B., et al. (2018) Effects of Aerobic Exercise on Metabolic Syndrome, Cardiorespiratory Fitness, and Symptoms in Schizophrenia Include Decreased Mortality. Frontiers in Psychiatry, 9, 690. https://doi.org/10.3389/fpsyt.2018.00690

[6] Walker, E.R., McGee, R.E. and Druss, B.G. (2015) Mortality in Mental Disorders and Global Disease Burden Implications: A Systematic Review and Meta-Analysis. JAMA Psychiatry, 72, 334-341. https://doi.org/10.1001/jamapsychiatry.2014.2502

[7] Dickens, C.M., Gossage-Worrall, R., Holt, R.I., Barnard, K., Carey, M.E., Doherty, Y., Wright, S., et al. (2016) STEPWISE-Structured Lifestyle Education for People with Schizophrenia: A Study Protocol for a Randomised Controlled Trial. Trials, 17, Article No. 475. https://doi.org/10.1186/s13063-016-1572-1

[8] Gossage-Worrall, R., Hind, D., Barnard-Kelly, K.D., Shiers, D., Etherington, A., Swaby, L. and STEPWISE Research Group (2019) Structured Lifestyle Education for People with Schizophrenia (STEPWISE): Mixed Methods Process Evaluation of a Group-Based Lifestyle Education Programme to Support Weight Loss in People with Schizophrenia. BMC Psychiatry, 19, 358. https://doi.org/10.1186/s12888-019-2282-5

[9] De Hert, M., Detraux, J., Van Winkel, R., Yu, W. and Correll, C.U. (2012) Metabolic and Cardiovascular Adverse Effects Associated with Antipsychotic Drugs. Nature Reviews Endocrinology, 8, 114-126. https://doi.org/10.1038/nrendo.2011.156

[10] McEvoy, J.P., Meyer, J.M., Goff, D.C., Nasrallah, H.A., Davis, S.M., Sullivan, L., Lieberman, J.A., et al. (2005) Prevalence of the Metabolic Syndrome in Patients with Schizophrenia: Baseline Results from the Clinical Antipsychotic Trials of Intervention Effectiveness (CATIE) Schizophrenia Trial and Comparison with National Estimates from NHANES III. Schizophrenia Research, 80, 19-32.

https://doi.org/10.1016/j.schres.2005.07.014 
[11] Saari, K.M., Lindeman, S.M., Viilo, K.M., Isohanni, M.K., Järvelin, M.R., Lauren, L.H., Koponen, H.J., et al. (2005) A 4-Fold Risk of Metabolic Syndrome in Patients with Schizophrenia: The Northern Finland 1966 Birth Cohort Study. The Journal of Clinical Psychiatry, 66, 559-563. https://doi.org/10.4088/JCP.v66n0503

[12] Vancampfort, D., Guelinkcx, H., Probst, M., Stubbs, B., Rosenbaum, S., Ward, P.B. and De Hert, M. (2015) Associations between Metabolic and Aerobic Fitness Parameters in Patients with Schizophrenia. The Journal of Nervous and Mental Disease, 203, 23-27. https://doi.org/10.1097/NMD.0000000000000229

[13] Bora, E., Akdede, B.B. and Alptekin, K. (2017) The Relationship between Cognitive Impairment in Schizophrenia and Metabolic Syndrome: A Systematic Review and Meta-Analysis. Psychological Medicine, 47, 1030.

https://doi.org/10.1017/S0033291716003366

[14] Kolenic, M., Franke, K., Hlinka, J., Matejka, M., Capkova, J., Pausova, Z., Hajek, T., et al. (2018) Obesity, Dyslipidemia and Brain Age in First-Episode Psychosis. Journal of Psychiatric Research, 99, 151-158. https://doi.org/10.1016/j.jpsychires.2018.02.012

[15] Siervo, M., Arnold, R., Wells, J.C.K., Tagliabue, A., Colantuoni, A., Albanese, E., Stephan, B.C.M., et al. (2011) Intentional Weight Loss in Overweight and Obese Individuals and Cognitive Function: A Systematic Review and Meta-Analysis. Obesity Reviews, 12, 968-983. https://doi.org/10.1111/j.1467-789X.2011.00903.x

[16] WHO World Health Organization (2019) Global Action Plan on Physical Activity 2018-2030: More active People for a Healthier World.

[17] Chudasama, Y.V., Khunti, K., Gillies, C.L., Dhalwani, N.N., Davies, M.J., Yates, T. and Zaccardi, F. (2020) Healthy Lifestyle and Life Expectancy in People with Multimorbidity in the UK Biobank: A Longitudinal Cohort Study. PLoS Medicine, 17, e1003332. https://doi.org/10.1371/journal.pmed.1003332

[18] Rhodes, R.E., Janssen, I., Bredin, S.S., Warburton, D.E. and Bauman, A. (2017) Physical Activity: Health Impact, Prevalence, Correlates and Interventions. Psychology \& Health, 32, 942-975. https://doi.org/10.1080/08870446.2017.1325486

[19] Soundy, A., Wampers, M., Probst, M., De Hert, M., Stubbs, B., Vancampfort, D., Ströhle, A., et al. (2013) Physical Activity and Sedentary Behaviour in Outpatients with Schizophrenia: A Systematic Review and Meta-Analysis. International Journal of Therapy and Rehabilitation, 20, 588-595. https://doi.org/10.12968/ijtr.2013.20.12.588

[20] Vancampfort, D., Probst, M., Scheewe, T., De Herdt, A., Sweers, K., Knapen, J., De Hert, M., et al. (2013) Relationships between Physical Fitness, Physical Activity, Smoking and Metabolic and Mental Health Parameters in People with Schizophrenia. Psychiatry Research, 207, 25-32. https://doi.org/10.1016/j.psychres.2012.09.026

[21] Stubbs, B., Williams, J., Gaughran, F. and Craig, T. (2016) How Sedentary Are People with Psychosis? A Systematic Review and Meta-Analysis. Schizophrenia Research, 171, 103-109. https://doi.org/10.1016/j.schres.2016.01.034

[22] Stubbs, B., Chen, L.J., Chung, M.S. and Ku, P.W. (2017) Physical Activity Ameliorates the Association between Sedentary Behavior and Cardiometabolic Risk among Inpatients with Schizophrenia: A Comparison versus Controls Using Accelerometry. Comprehensive Psychiatry, 74, 144-150.

https://doi.org/10.1016/j.comppsych.2017.01.010

[23] Ohi, K., Kataoka, Y., Shimada, T., Kuwata, A., Okubo, H., Kimura, K., Kawasaki, Y., et al. (2019) Meta-Analysis of Physical Activity and Effects of Social Function and Quality of Life on the Physical Activity in Patients with Schizophrenia. European 
Archives of Psychiatry and Clinical Neuroscience, 269, 517-527. https://doi.org/10.1007/s00406-018-0903-5

[24] Schuch, F., Vancampfort, D., Firth, J., Rosenbaum, S., Ward, P., Reichert, T., Stubbs, B., et al. (2017) Physical Activity and Sedentary Behavior in People with Major Depressive Disorder: A Systematic Review and Meta-Analysis. Journal of Affective Disorders, 210, 139-150. https://doi.org/10.1016/j.jad.2016.10.050

[25] Kamphuis, C.B., Turrell, G., Giskes, K., Mackenbach, J.P. and Van Lenthe, F.J. (2012) Socioeconomic Inequalities in Cardiovascular Mortality and the Role of Childhood Socioeconomic Conditions and Adulthood Risk Factors: A Prospective Cohort Study with 17-Years of Follow Up. BMC Public Health, 12, Article No. 1045. https://doi.org/10.1186/1471-2458-12-1045

[26] Mittal, V.A., Vargas, T., Osborne, K.J., Dean, D., Gupta, T., Ristanovic, I., Shankman, S.A., et al. (2017) Exercise Treatments for Psychosis: A Review. Current Treatment Options in Psychiatry, 4, 152-166. https://doi.org/10.1007/s40501-017-0112-2

[27] Lee, E.H., Hui, C.L., Chang, W.C., Chan, S.K., Li, Y.K., Lee, J.T., Chen, E.Y., et al. (2013) Impact of Physical Activity on Functioning of Patients with First-Episode Psychosis-A 6 Months Prospective Longitudinal Study. Schizophrenia Research, 150, 538-541. https://doi.org/10.1016/j.schres.2013.08.034

[28] Callaghan, P. (2004) Exercise: A Neglected Intervention in Mental Health Care? Journal of Psychiatric and Mental Health Nursing, 11, 476-483. https://doi.org/10.1111/j.1365-2850.2004.00751.x

[29] Firth, J., Rosenbaum, S., Stubbs, B., Vancampfort, D., Carney, R. and Yung, A. (2016) Preferences and Motivations for Exercise in Early Psychosis. Acta Psychiatrica Scandinavica, 134, 83-84. https://doi.org/10.1111/acps.12562

[30] Alvarez-Jimenez, M., Gonzalez-Blanch, C., Crespo-Facorro, B., Hetrick, S., Rodriguez-Sanchez, J.M., Perez-Iglesias, R. and Luis, J. (2008) Antipsychotic-Induced Weight Gain in Chronic and First-Episode Psychotic Disorders. CNS Drugs, 22, 547-562. https://doi.org/10.2165/00023210-200822070-00002

[31] Blouin, M., Tremblay, A., Jalbert, M.E., Venables, H., Bouchard, R.H., Roy, M.A and Alméras, N. (2008) Adiposity and Eating Behaviors in Patients under Second Generation Antipsychotics. Obesity, 16, 1780-1787.

https://doi.org/10.1038/oby.2008.277

[32] Treuer, T., Hoffmann, V.P., Chen, A.K.P., Irimia, V., Ocampo, M., Wang, G., Holt, S., et al. (2009) Factors Associated with Weight Gain during Olanzapine Treatment in Patients with Schizophrenia or Bipolar Disorder: Results from a Six-Month Prospective, Multinational, Observational Study. The World Journal of Biological Psychiatry, 10, 729-740. https://doi.org/10.1080/15622970903079507

[33] Wirshing, D.A. (2004) Schizophrenia and Obesity: Impact of Antipsychotic Medications. Journal of Clinical Psychiatry, 65, 13-26.

[34] De Hert, M., Schreurs, V., Vancampfort, D. and Van Winkel, R. (2009) Metabolic Syndrome in People with Schizophrenia: A Review. World Psychiatry, 8, 15-22. https://doi.org/10.1002/j.2051-5545.2009.tb00199.x

[35] Mitchell, A.J., Vancampfort, D., Sweers, K., van Winkel, R., Yu, W. and De Hert, M. (2011) Prevalence of Metabolic Syndrome and Metabolic Abnormalities in Schizophrenia and Related Disorders-A Systematic Review and Meta-Analysis. Schizophrenia Bulletin, 39, 306-318. https://doi.org/10.1093/schbul/sbr148

[36] Annamalai, A., Kosir, U. and Tek, C. (2017) Prevalence of Obesity and Diabetes in Patients with Schizophrenia. World Journal of Diabetes, 8, 390.

https://doi.org/10.4239/wjd.v8.i8.390 
[37] Aucoin, M., LaChance, L., Cooley, K. and Kidd, S. (2020) Diet and Psychosis: A Scoping Review. Neuropsychobiology, 79, 20-42. https://doi.org/10.1159/000493399

[38] Derbyshire, E.J. (2017) Flexitarian Diets and Health: A Review of the Evidence-Based Literature. Frontiers in Nutrition, 3, 55. https://doi.org/10.3389/fnut.2016.00055

[39] Fernández-San-Martín, M.I., Martín-López, L.M., Masa-Font, R., Olona-Tabueña, N., Roman, Y., Martin-Royo, J., Flores-Mateo, G., et al. (2014) The Effectiveness of Lifestyle Interventions to Reduce Cardiovascular Risk in Patients with Severe Mental Disorders: Meta-Analysis of Intervention Studies. Community Mental Health Journal, 50, 81-95. https://doi.org/10.1007/s10597-013-9614-6

[40] Caemmerer, J., Correll, C.U. and Maayan, L. (2012) Acute and Maintenance Effects of Non-Pharmacologic Interventions for Antipsychotic Associated Weight Gain and Metabolic Abnormalities: A Meta-Analytic Comparison of Randomized Controlled Trials. Schizophrenia Research, 140, 159-168. https://doi.org/10.1016/j.schres.2012.03.017

[41] Cimo, A., Stergiopoulos, E., Cheng, C., Bonato, S. and Dewa, C.S. (2012) Effective Lifestyle Interventions to Improve Type II Diabetes Self-Management for Those with Schizophrenia or Schizoaffective Disorder: A Systematic Review. BMC Psychiatry, 12, 1-9. https://doi.org/10.1186/1471-244X-12-24

[42] Bruins, J., Jörg, F., Bruggeman, R., Slooff, C., Corpeleijn, E. and Pijnenborg, M. (2014) The Effects of Lifestyle Interventions on (Long-Term) Weight Management, Cardiometabolic Risk and Depressive Symptoms in People with Psychotic Disorders: A Meta-Analysis. PLoS ONE, 9, e112276.

https://doi.org/10.1371/journal.pone.0112276

[43] Gurusamy, J., Gandhi, S., Damodharan, D., Ganesan, V. and Palaniappan, M. (2018) Exercise, Diet and Educational Interventions for Metabolic Syndrome in Persons with Schizophrenia: A Systematic Review. Asian Journal of Psychiatry, 36, 73-85. https://doi.org/10.1016/j.ajp.2018.06.018

[44] Holt, R.I., Gossage-Worrall, R., Hind, D., Bradburn, M.J., McCrone, P., Morris, T., Dickens, C.M., et al. (2019) Structured Lifestyle Education for People with Schizophrenia, Schizoaffective Disorder and First-Episode Psychosis (STEPWISE): Randomised Controlled Trial. The British Journal of Psychiatry, 214, 63-73. https://doi.org/10.1192/bjp.2018.167

[45] Álvarez-Jiménez, M., Martínez-García, O., Pérez-Iglesias, R., Ramírez, M.L., Vázquez-Barquero, J.L. and Crespo-Facorro, B. (2010) Prevention of AntipsychoticInduced Weight Gain with Early Behavioural Intervention in First-Episode Psychosis: 2-Year Results of a Randomized Controlled Trial., Schizophrenia Research, 116, 16-19. https://doi.org/10.1016/j.schres.2009.10.012

[46] Marshall, M., Barrowclough, C., Drake, R., Husain, N., Lobban, F., Lovell, K., Pedley, R., et al. (2015) The HELPER Programme: Healthy Living and Prevention of Early Relapse-Three Exploratory Randomised Controlled Trials of Phase-Specific Interventions in First-Episode Psychosis. NIHR Journals Library, Southampton. https://doi.org/10.3310/pgfar03020

[47] Curtis, J., Watkins, A., Rosenbaum, S., Teasdale, S., Kalucy, M., Samaras, K. and Ward, P.B. (2016) Evaluating an Individualized Lifestyle and Life Skills Intervention to Prevent Antipsychotic-Induced Weight Gain in First-Episode Psychosis. Early Intervention in Psychiatry, 10, 267-276. https://doi.org/10.1111/eip.12230

[48] Firth, J., Carney, R., Elliott, R., French, P., Parker, S., McIntyre, R., Yung, A.R., et al. (2018) Exercise as an Intervention for First-Episode Psychosis: A Feasibility Study. Early Intervention in Psychiatry, 12, 307-315. https://doi.org/10.1111/eip.12329 
[49] Teasdale, S.B., Ward, P.B., Rosenbaum, S., Watkins, A., Curtis, J., Kalucy, M. and Samaras, K. (2016) A Nutrition Intervention Is Effective in Improving Dietary Components Linked to Cardiometabolic Risk in Youth with First-Episode Psychosis. British Journal of Nutrition, 115, 1987-1993.

https://doi.org/10.1017/S0007114516001033

[50] Teasdale, S.B., Curtis, J., Ward, P.B., Watkins, A., Lederman, O., Rosenbaum, S., Samaras, K., et al. (2019) The Effectiveness of the Keeping the Body in Mind Extend Pilot Lifestyle Program on Dietary Intake in First-Episode Psychosis: Two-Year Outcomes. Obesity Research \& Clinical Practice, 13, 214-216.

https://doi.org/10.1016/j.orcp.2019.02.003

[51] Abdel-Baki, A., Brazzini-Poisson, V., Marois, F., Letendre, É. and Karelis, A.D. (2013) Effects of Aerobic Interval Training on Metabolic Complications and Cardiorespiratory Fitness in Young Adults with Psychotic Disorders: A Pilot Study. Schizophrenia Research, 149, 112-115. https://doi.org/10.1016/j.schres.2013.06.040

[52] Lambden, B., Berge, J. and Forsell, Y. (2018) Structured Physical Exercise and Recovery from First Episode Psychosis in Young Adults, the FitForLife Study. Psychiatry Research, 267, 346-353. https://doi.org/10.1016/j.psychres.2018.06.001

[53] Smith, J., Griffiths, L.A., Band, M., Hird-Smith, R., Williams, B., Bold, J., Horne, D., et al. (2020) Early Intervention in Psychosis: Effectiveness and Implementation of a Combined Exercise and Health Behavior Intervention within Routine Care. Frontiers in Endocrinology, 11, 825. https://doi.org/10.3389/fendo.2020.577691

[54] Osborn, D.P., Nazareth, I. and King, M.B. (2007) Physical Activity, Dietary Habits and Coronary Heart Disease Risk Factor Knowledge amongst People with Severe Mental Illness. Social Psychiatry and Psychiatric Epidemiology, 42, 787-793. https://doi.org/10.1007/s00127-007-0247-3 